\title{
Powder for Concentrate and Solution for Solution for Infusion Dosage Form
}

National Cancer Institute

\section{Source}

National Cancer Institute. Powder for Concentrate and Solution for Solution for Infusion

Dosage Form. NCl Thesaurus. Code C149809.

Medicinal product consisting of a powder for concentrate for solution for infusion and a solution for solution for infusion, intended for the preparation of a solution for infusion. 